\title{
DNase and Gelatinase Activities Of $\beta$-Hemolysin Aeromonas hydrophila Isolated from Catfish (Clarias batrachus)
}

\author{
Rahayu Kusdarwati ${ }^{1 *}$, Muhamad Amin ${ }^{1}$ and Aldiansyah Budi Wardana ${ }^{2}$ \\ ${ }^{1}$ Department of Aquaculture, Faculty of Fisheries and Marine, Universitas Airlangga, Jl. Mulyorejo, \\ Mulyorejo, Surabaya 60115, Indonesia \\ ${ }^{2}$ Study Program of Aquaculture, Faculty of Fisheries and Marine, Universitas Airlangga, Jl. \\ Mulyorejo, Mulyorejo, Surabaya 60115, Indonesia
}

*Correspondence :

rahayu.k@fpk.unair.ac.id

Received : 2021-03-12

Accepted : 2021-05-09

Keywords :

$\beta$-hemolysin, DNase, Gelatinase

\begin{abstract}
Aeromonas hydrophila infection can cause mass mortality in fish and result in economic losses for farmers. These are bacterium that secrete substances or compounds that support its virulence by producing toxins and extracellular proteins in the form of enzymes. This study aimed to determine the activity of DNase enzyme, and gelatinase enzyme of $\beta$ hemolysin toxin A. hydrophila isolated from catfish (Clarias batrachus). This research was carried out in November 2020 in Dukuh Tengah Village, Buduran District, Wedoro Village, Waru District, Wadung Asri Village, Waru District and Keboan Sikep Village, Gedangan District. The sampling technique was carried out by researchers by following activities in the field and visiting correspondents directly in the catfish cultivator ponds, then the catfish samples were carried out by biochemical tests and toxin and enzyme activity tests to obtain the information and data needed. The results showed that $A$. hydrophila bacteria in catfish produced positive $\beta$-hemolysin toxin, DNase enzyme, and gelatinase enzyme. The research concluded that 10 isolates of $A$. hydrophila bacteria isolated from catfish (C. batrachus) in Sidoarjo showed the activity of $\beta$ hemolysin toxin, DNase enzyme, and gelatinase enzyme.
\end{abstract}

\section{INTRODUCTION}

The production of aquaculture in Indonesia has increased by an average of $27.84 \%$ each year. The percentage increase in the average aquaculture production in Indonesia is the highest compared to the top ten world aquaculture-producing countries. China, as a world fishery-producing country, has an average production increase of only $5.29 \%$. The percentage of aquaculture production is still below the average world aquaculture production (Direktorat Jenderal Perikanan Budidaya, 2015). In 2017-2018 the production of catfish farming in Indonesia increased from 841.75 thousand tons to 1.81 million tons with an increase of $114.82 \%$ (Kementerian Kelautan dan Perikanan, 2018). East Java is the second largest province for catfish aquaculture production. Sidoarjo is a contributor to catfish production of 75,720 tons in 2018 (Badan Pusat Statistik Jawa Timur, 2018).

Many pathogenic bacteria are of concern in fish diseases, but only a few species of pathogenic bacteria are responsible for the economic losses in fish farming worldwide (Sudheesh et al., 
2012). Aeromonas hydrophila is a pathogenic bacterium that causes mass death of fish worldwide, resulting in economic losses for farmers (Janda and Abbott, 2010). A. hydrophila and other strains are known to be capable of producing extracellular toxins such as hemolysin which greatly determine the pathogenicity and virulence level of bacteria. A. hydrophila produces a $\beta$ hemolysin toxin which can lyse red blood cells in a fast time (Mangunwardoyo et al., 2009). The activity of the hemolysin toxin causes a reddish color (hemorrhage) on the surface of the fish's skin (Li et al., 2013). Several pathogenic bacteria have been known to produce extracellular DNase, but the benefits of utilizing their enzyme activity are not fully understood (Sunita et al., 2015).

Fox and Holtman (1968) stated that DNase helps in the spread of infectious pathogenic bacteria to the host and provides nucleotides for the rapid growth of bacteria through DNA hydrolysis. Gelatinase enzymes are produced by several species of bacteria to hydrolyze gelatin into compounds (polypeptides, peptides and amino acids), this enzyme is used by bacteria to be able to pass through the host cell membrane and the results of gelatin hydrolysis are used by bacteria for metabolic processes. (Balan et al., 2012). Chandrarathna et al. (2018) stated that the activity of $\beta$-hemolysin toxin, DNase and gelatinase determines the pathogenicity of $A$. hydrophila bacteria in fish. Based on this background, a study was conducted to provide information about isolates that showed $\beta$-hemolysin, DNase and gelatinase activity in $A$. hydrophila so that they could help in disease management in catfish in Sidoarjo.

\section{METHODOLOGY}

\section{Place and Time}

This research was conducted in November 2020 in Dukuh Tengah Village, Buduran District, Wedoro Village, Waru District, Wadung Asri Village, Waru
District and Keboan Sikep Village, Gedangan District, Sidoarjo Regency.

\section{Research Materials}

The tools used in this study were section set, syringe, laminar airflow, tray, analytical scale (Scout Pro), loop needle (Usebeck 5431), petri dish (Iwaki), incubator (Memmert in 55), test tube rack, test tube (Iwaki), bunsen (OMM), dropper (Pyrex), spatula, Erlenmeyer (Pyrex), measuring cup (Pyrex), object glass, autoclave (Hirayama), microscope, optilab, label, matches, refrigerator (Ikeda), hot plate (Cimarec), magnetic stirrer, measuring pipette (Iwaki), bulb (D\&N), syringe (OneMed), nets, and vacutainer (Vacculab).

The materials used in this study were $70 \%$ alcohol, Aeromonas selective agar medium, blood agar medium, sheep blood 5\%, DNase agar medium, methyl green $0.05 \%$, nutrient gelatin medium, spirits, phosphate-buffered saline, gram staining reagent, plastic wrap, packing plastic, and immersion oil.

\section{Research Design}

This study used a survey method by taking samples at the location directly to obtain A. hydrophila bacterial isolates in catfish (Clarias batrachus). Sampling was carried out on catfish cultivation pond plots. The samples taken were catfish showing clinical symptoms of $A$. hydrophila infection, then isolation, identification by biochemical tests and activity tests of hemolysin, DNase and gelatinase were taken.

\section{Work Procedure Sampling}

The catfish taken for the sample is catfish measuring 25-35 cm, aged 2-3 months and weighing 100-150 grams. The fish used are catfish that show clinical symptoms such as red spots (hemorrhagic) on the skin surface, flatulence (dropsy), protruding eyes (exophthalmia), scaly fins and slow-moving fish ulcers and hemorrhage on the surface of the fish's 
body and fish swim slowly on the surface of the water (Lili et al., 2019).

\section{Equipment Sterilization}

The initial stage of this research is sterilization. The equipment used is a petri dish, test tube, Erlenmeyer, sectio set, wrapped in heat-resistant plastic (HDPE) and put in an autoclave at a temperature of $121{ }^{\circ} \mathrm{C}$ with a pressure of 15 psi for 15 minutes. All surfaces and walls of laminar airflow are cleaned with $70 \%$ alcohol spray. The fan is turned on to circulate the air to keep it sterile. The media that has been made is put into a sterile Erlenmeyer which is tightly closed with cotton, then put in an autoclave at a temperature of $121{ }^{\circ} \mathrm{C}$ with a pressure of 15 psi for 15 minutes (Anggraini et al., 2016).

\section{Isolation of Bacteria on Catfish (Clarias batrachus)}

Bacteria were isolated using a loop needle then planted on ASA (Aeromonas Selective Agar) media and incubated at $37^{\circ} \mathrm{C}$ for 24 hours. Testing of isolates was carried out using a 1000x magnification microscope after Gram staining of the bacterial isolates. Observations were carried out with a microscope that had been added with immersion oil and then observed under a 1000x magnification microscope to see the morphology of bacterial cells.

\section{Identification of Aeromonas hydrophila on Catfish (Clarias batrachus)}

Identification was carried out by macroscopic test with colony morphology observation, microscopic test in the form of gram stain and biochemical test. The gram stain test was carried out with reagent gram stain using a microscope that had been installed with optilab to observe the color and shape of the bacteria, and continued with biochemical tests such as catalase test, oxidase test, indole test, motility test, TSIA test, and others.

\section{Aeromonas hydrophila Hemolysin Activity Test}

A hemolysin test is carried out using blood agar media. Isolates were planted in blood agar base with the addition of sheep blood that had been fibrinated as much as $5 \%$ of blood agar base, then incubated at $37{ }^{\circ} \mathrm{C}$ for $18-24$ hours. A positive result if a clear zone is formed around the colony on the media, indicates that the microbe is pathogenic (Sukmadewi et al., 2017).

\section{Aeromonas hydrophila DNase Activity Test \\ DNase test is performed using DNase} agar. Bacteria to be tested are inoculated on DNase agar plate which has been added with $0.005 \%$ methyl green, then incubated at $37^{\circ} \mathrm{C}$ for 24 hours. After incubation, the DNase agar plate was immersed with $1 \mathrm{~N}$ $\mathrm{HCl}$ for 5 minutes (Chu et al., 2013). A positive result if a clear zone is formed around the colony indicates that there is DNase activity which hydrolyzes deoxyribonuclease (Kateete et al., 2010).

\section{Aeromonas hydrophila Gelatinase Activity Test}

The gelatinase test was carried out using bacteria that had been pure culture using a loop needle, then inserted into the nutrient gelatin media in the middle of the media. Bacteria that have been inoculated into gelatin media are stored in an incubator at $37^{\circ} \mathrm{C}$ for \pm 3 days. After waiting for \pm 3 days, observe utilizing a test tube containing bacterial isolates stored in the refrigerator at $4{ }^{\circ} \mathrm{C}$ (Prihanto et al., 2018). Wait 25 minutes for the jar in the refrigerator. Furthermore, observations were made including whether or not the gelatin was melted compared to the control. If there is melting of gelatin, it indicates that the bacteria are capable of producing gelatinase exoenzymes (Putri et al., 2017).

\section{Data Analysis}

The data obtained were analyzed descriptively, namely about the activity of Hemolysin, DNase and Gelatinase from 
Aeromonas hydrophila isolates that had been isolated in catfish (C. batrachus) in Sidoarjo.

\section{RESULTS AND DISCUSSION Aeromonas Identification \\ hydrophila}

Ten isolates were identified by the bacterium Aeromonas hydrophila by macroscopic and microscopic observations. Macroscopic observations include the shape and color of the Aeromonas hydrophila colony and microscopic observations including the shape of the gram stain, the form of short stem bacteria measuring 1.90-3.42 $\mu \mathrm{m}$, red-colored using a 1000x magnification microscope can be seen in Figure 1.

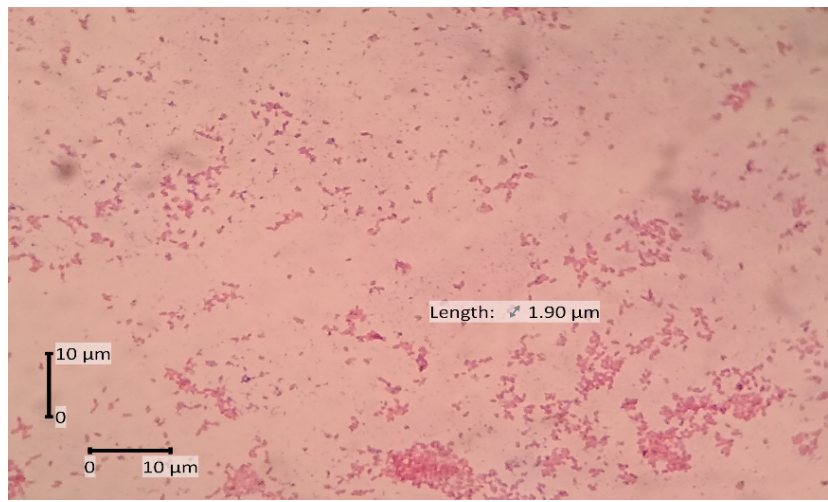

Figure 1. Cell morphology of A. hydrophila.

\section{Hemolysin Activity}

The results of observations on 10 bacterial isolates identified as $A$. hydrophila showed hemolysin activity. Zones were formed on the agar blood medium from the inoculation of $A$. hydrophila bacteria which had been incubated for 24 hours at $37^{\circ} \mathrm{C}$. According to Mangunwardoyo et al. (2010), perfect hemolysin ( $\beta$-hemolysin) can be seen from the formation of a clear zone around the A. hydrophila colony which can be seen in Figure 2.

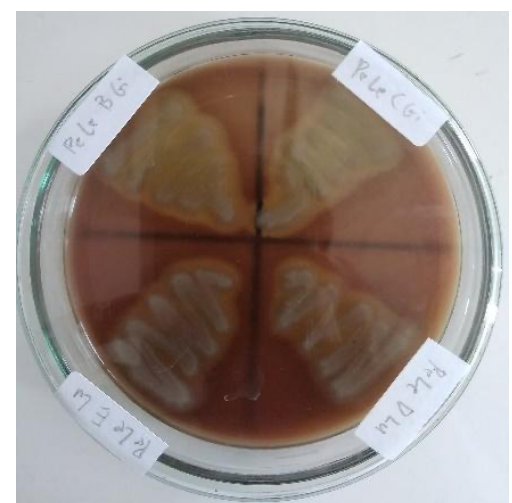

Figure 2. $\beta$-hemolysin activity of $A$. hydrophila.

\section{DNase Activity}

The results of observations on 10 bacterial isolates were identified as $A$. hydrophila positively showed DNase activity. Zones were formed on DNase agar from the inoculation of A. hydrophila which had been incubated for 24 hours at $37^{\circ} \mathrm{C}$ (Majumdar et al., 2007). The clear zone formed can be seen in Figure 3. 
Figure 3. DNase activity of $A$. hydrophila.



\section{Gelatinase Activity}

The results of observations on 10 bacterial isolates identified as $A$. hydrophila showed positive gelatinase activity. Gelatin liquefaction occurs in nutrient gelatin media from the inoculation of $A$. hydrophila bacteria which has been incubated for 72 hours at $37^{\circ} \mathrm{C}$, then the test tube containing bacterial isolates is stored in a refrigerator at $4{ }^{\circ} \mathrm{C}$ (Prihanto et al., 2018). Gelatin melting can be seen in Figure 4.

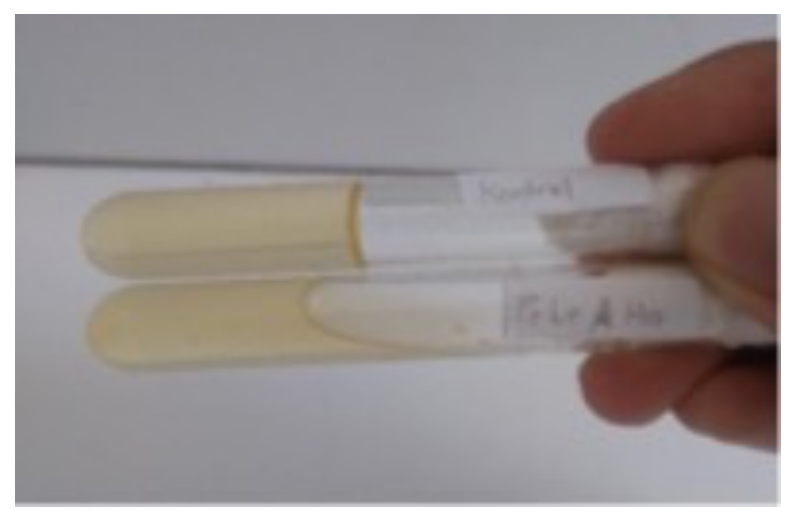

Figure 4. Gelatinase activity of A. hydrophila, A (Control: there is no melting of gelatin); $\mathrm{B}$ (Treatment: there is melting of gelatin).

A. hydrophila is a pathogen that attacks various types of freshwater fish and causes Motile Aeromonas Septicemia (MAS) worldwide. MAS causes pathological changes in fish such as tail/ fin rot, hemorrhagic septicemia all over the body surface, local bleeding especially in the gills and anus, ulcers, abscesses, exophthalmia and flatulence. Internally, there may be ascitic fluid accumulation, anemia and damage to organs, especially the kidneys and liver (Austin and Austin, 2016). The virulence factors produced by A. hydrophila include hemolysin, DNase, and Gelatinase, these factors affect the virulence level of $A$. hydrophila (Hossain et al., 2020).
Catfish samples suspected of being infected with $A$. hydrophila were isolated from four areas in Sidoarjo, East Java, namely Dukuh Tengah Buduran, Wedoro Waru, Wadung Asri Waru and Keboan Sikep Gedangan. Ten isolates from 25 isolates, as much as $40 \%$ were identified as $A$. hydrophila by biochemical tests according to Austin and Austin (2007). Ten A. hydrophila isolates showed bacterial colonies of round shape, flat edges, slightly convex elevation, yellow color, gram-negative with rod-shaped cells ranging in size from 1.90 to $3.37 \mu \mathrm{m}$. Austin and Austin (2016) stated that A. hydrophila is a gram-negative bacterium with rod-shaped cells measuring 1.0-3.5 
$\mu \mathrm{m}$ and Himedia (2016) that A. hydrophila colonies are large round and yellow.

Hemolysin test for A. hydrophila bacteria (10 isolates) showed hemolysin activity with the formation of a bright zone ( $\beta$-hemolysin) around the colony. This is supported by research by Pandey et al. (2010) which states that $A$. hydrophila bacteria produce $\beta$ hemolysin toxin which is one of the important virulence factors of pathogenic bacteria. In the study by Majumdar et al. (2007), A. hydrophila isolates isolated from catfish (C. batrachus) showed $\beta$ hemolysin activity. Abd-El-Malek (2017) also stated that $100 \%$ A. hydrophila isolates produced $\beta$ hemolysin toxin. Rahim et al. (2004) added that $A$. hydrophila bacteria produces two types of hemolysin toxins, namely a hemolysin and $\beta$ hemolysin. Angka (2001) states that hemolysin is an enzyme capable of lysing red blood cells and freeing hemoglobin (a protein in blood that gives red blood cells their red color).

A. hydrophila also produce hemolysin toxin which plays a role in the infection and spread of bacteria in the host body which causes cell damage and cell mortality (Qosimah et al., 2020). Bhakdi et al. (1996) added that in addition to being able to lyse red blood cells, this toxin also destroys tissue cells and the first immune system of the host cell (fish), thus hemolysin toxin directly increases the infection of these bacteria. Mangunwardoyo et al. (2009) added that A. hydrophila produces $\beta$ hemolysin toxin which can lyse blood quickly and completely, and plays a role in infecting fish bodies (hosts) through the mechanism of action of $\beta$-hemolysin toxin which is released when $A$. hydrophila bacteria attaches to the surface. fish body. This $\beta$ hemolysin toxin causes lesions and fatal hemorrhage in catfish (Majumdar et al., 2007).

DNase test for A. hydrophila that had been inoculated on DNase agar media, all (10 isolates) showed DNase activity with the formation of a bright zone around the colony. This is following the research of
Majumdar et al. (2007) which stated that A. hydrophila bacteria isolated from catfish (C. batrachus) showed that A. hydrophila was positive for producing the DNase enzyme. In the study of Yadav et al. (2014), A. hydrophila isolates were $100 \%$ positive to produce the DNase enzyme. The DNase activity of $A$. hydrophila bacteria isolates can cause disease in fish and humans. Pemberton et al. (1997) added the role of DNase Aeromonas sp. It is considered important for bacterial nutrition because the DNase enzyme regenerates nucleic acids into phosphorus and nitrogen which will be used as a source of nutrition for Aeromonas sp., the DNase enzyme is a virulence factor of $A$. hydrophila bacteria (Chu et al., 2013).

The gelatinase test for $A$. hydrophila bacteria as many as 10 isolates on nutrient gelatin medium showed the presence of gelatinase activity which was indicated by the occurrence of liquefaction in the gelatin medium (Fitriyah, 2017). This is in accordance with the research of Majumdar et al. (2007) which stated that $A$. hydrophila bacteria isolated from catfish (C. batrachus) showed positive results in producing gelatinase enzymes. In a study by Yadav et al. (2014), A. hydrophila isolates were $100 \%$ positive to produce gelatinase enzymes. The gelatinase enzyme in A. hydrophila can break down gelatin in fish into amino acids which are then used by bacteria to be used in metabolic processes (Fitriyah, 2017).

Murwani et al. (2017) state that $A$. hydrophila bacteria has a fimbria that acts as an attachment to the surface of the host cell and acts as an adhesin (a medium for bacteria to infect the host), then $A$. hydrophila bacteria produce several extracellular proteins and toxins that play a role in infection in the host. Degradation of tissues and proteins in the host due to extracellular protein and hemolysin toxin produced by $A$. hydrophila bacteria is used as an energy source for multiplication. $A$. hydrophila by attaching the fimbriae directly to the host cell and mucosal receptors. According to Murwani et al. (2017), these bacteria then spread 
through blood circulation, multiplication, biofilm formation and release toxins, causing damage to the host's tissues.

According to Arwin et al. (2016), extracellular proteins are produced by $A$. hydrophila such as DNase and gelatinase enzymes. Fox and Holtman (1968) stated that the DNase enzyme helps pathogenic bacteria in infecting the host and provides nucleic acid for the rapid growth of bacteria through DNA hydrolysis. Buchanan et al. (2006) added that pathogenic bacteria produce the DNase enzyme to escape from extracellular traps. Citterio and Biavasco (2015) added that extracellular traps such as neutrophils, eosinophils and macrophages function to capture and kill pathogenic bacteria, thereby reducing their spread to infected hosts (fish).

Meanwhile, the gelatinase enzyme is produced by pathogenic bacteria to hydrolyze gelatin into polypeptides, peptides and amino acids (Petersen and McLaughlin, 2016). Balan et al. (2012) added that the gelatinase enzyme is used by bacteria to be able to pass through the host cell membrane and the results of gelatin hydrolysis are used by bacteria for metabolic processes. So, it can be said that $\beta$ hemolysin toxin, DNase enzyme, and gelatinase enzyme produced by $A$. hydrophila are important virulence factors in the infection of $A$. hydrophila bacteria to fish (hosts).

\section{CONCLUSION}

Based on the results of the research that has been done, catfish (C. batrachus) cultivated in Buduran Middle Hamlet, Wedoro Waru, Wadung Asri Waru and Keboan Sikep Gedangan Sidoarjo showed $\beta$ hemolysin toxin, DNase enzyme and gelatinase enzyme by $100 \%$ in all isolates.

\section{ACKNOWLEDGMENT}

The researchers would like to thank colleagues who have helped with the completion of this research.

\section{REFERENCES}

Abd-El-Malek, A.M., 2017. Incidence and virulence characteristics of Aeromonas spp. in fish. Veterinary world, 10(1), pp.34-37. https://doi. org/10.14202/vetworld.2017.34-37

Anggraini, R., Aliza, D. and Mellisa, S., 2016. Identifikasi bakteri Aeromonas hydrophila dengan uji mikrobiologi pada lele dumbo (Clarias gariepinus) dibudi-dayakan di Kecamatan Baitussalam Kabupaten Aceh Besar. Jurnal Ilmiah Mahasiswa Kelautan Perikanan Unsyiah, 1(2), pp.270286. http://jim.unsyiah.ac.id/fkp/a rticle/view/546

Angka, S.L., 2001. Studi karakterisasi dan patologi Aeromonas hydrophila pada ikan lele dumbo (Clarias gariepinus). Makalah Falsafah Sains, Program Pascasarjana, pp.339-350.

Arwin, M., Ijong, F.G. and Tumbol, R., 2016. Characteristics of Aeromonas hydrophila isolated from Tilapia (Oreochromis niloticus). Aquatic science \& management, 4(2), pp.5255. https://doi.org/10.35800/jasm. 4.2.2016.14450

Austin, B. and Austin, D.A., 2007. Bacterial fish pathogens: Disease of farmed and wild fish. Ellis Horwood Limited, England, p. 215.

Austin, B. and Austin, D.A., 2016. Bacterial fish pathogens disease of farmed and wild fish sixth edition. Springer International Publishing, Switzerland, pp.167-171.

Badan Pusat Statistik Jawa Timur, 2018. Produksi Perikanan Budidaya Tambak menurut Kabupaten/Kota di Jawa Timur. https://jatim.bps.go.id /statictable/2018/11/14/1411/pro duksi-perikanan-budidaya-tambakmenurut-kabupaten-kota-di-jawatimur-ton-2010-2017.html

Balan, S.S., Nethaji, R., Sankar, S. and Jayalakshmi, S., 2012. Production of gelatinase enzyme from Bacillus spp. isolated from the sediment sample of Porto Novo Coastal sites. Asian Pacific Journal of Tropical Biomedicine, 2(3), pp.1811-1816. 
https://doi.org/10.1016/S2221-16

91(12)60500-0

Bhakdi, S., Bayley, H., Valeva, A., Walev, I., Walker, B., Weller, U., Kehoe, M. and Palmer, M., 1996. Staphylococcal Alpha-Toxin, Streptolysin-O, and Escherichia coli hemolysin: Prototypes of poreforming bacterial cytolysins. Archives of microbiology, 165, pp.7379. http://dx.doi.org/10.1007/s002 030050300

Buchanan, J.T., Simpson, A.J., Aziz, R.K., Liu, G.Y., Kristian, S.A., Kotb, M., Feramisco J. and Nizet, V., 2006. DNase expression allows the pathogen group A Streptococcus to escape killing in neutrophil extracellular traps. Current Biology, 16(4), pp.396-400. https://doi.org/ 10.1016/j.cub.2005.12.039

Chandrarathna, H.P.S.U., Nikapitiya, C., Dananjaya, S.H.S., Wijerathne, C.U.B., Wimalasena, S.H.M.P., Kwun, H.J., Heo, G.J., Lee, J. and De Zoysa, M., 2018. Outcome of coinfection with opportunistic and multidrug resistant Aeromonas hydrophila and $A$. veronii in zebrafish: Identification, characterization, pathogenicity and immune responses. Fish \& shellfish immunology, 80(1), pp.573-581. https://doi.org/10.1016/j.fsi.2018. 06.049

Chu, W., Liu, Y., Jiang, Y., Zhu, W. and Zhuang, X., 2013. Production of Nacyl homoserine lactones and virulence factors of waterborne Aeromonas hydrophila. Indian journal of microbiology, 53(3), pp.264-268. DOI $10.1007 / s 12088-$ 013-0381-4

Citterio, B. and Biavasco, F., 2015. Aeromonas hydrophila virulence. Virulence, 6(5), pp.417-418. https://dx.doi.org/10.1080\%2F215 05594.2015.1058479

Direktorat Jendral Perikanan Budidaya, 2015. Komoditas andalan Indonesia masuki jajaran produsen ikan terbesar dunia. http://www.djpb.kk p.go.id/index.php/arsip/c/258/ko moditas-andalan-indonesia-masukijajaran-produsen-ikan-terbesarunia/

Fitriyah, U.R., 2017. Isolasi dan identifikasi molekuler bakteri endofit akar mangrove Sonneratia alba penghasil enzim gelatinase. Doctoral dissertation, Universitas Brawijaya, pp. 9-10.

Fox, J.B. and Holtman, D.F., 1968. Effect of anaerobiosis on staphylococcal nuclease production. Journal of Bacteriology, 95(5), pp.1548-1550. https://doi.org/10.1128/jb.95.5.15 48-1550.1968

HiMedia Laboratories Pvt. Ltd., 2016. MAeromonas selective agar base (Havelaar) A-516. Swastik Disha Business Park, Via Vadhani Mumbai. India. pp.1-2

Hossain, S., De Silva, B.C.J., Dahanayake, P.S., De Zoysa, M. and Heo, G.J., 2020. Phylogenetic characteristics, virulence properties and antibiogram profile of Motile Aeromonas spp. Isolated from Ornamental Guppy (Poecilia reticulata). Archives of Microbiology, 202, pp.501-509. https://doi.org/1 0.1007/s00203-019-01762-5

Janda, J.M. and Abbott, S.L., 2010. The genus Aeromonas: Taxonomy, pathogenicity, and infection. Clinical Microbiology Review, 23(1), pp.3573. https://doi.org/10.1128/CMR.0 0039-09

Kateete, D.P., Kimani, C.N., Katabazi, F.A., Okeng, A., Okee, M.S., Nanteza, A., Joloba, M.L. and Najjuka, F.C., 2010. Identification of Staphylococcus aureus: DNase and mannitol salt agar improve the efficiency of the tube coagulase test. Annals of Clinical Microbiology and Antimicrobials, 9(1), pp.1-7. https:/ /doi.org/10.1186/1476-0711-9-23

Kementerian Kelautan dan Perikanan., 2018. Tunjukkan pertumbuhan positif KKP catat PDB perikanan $R p$ 59,98 triliun. https://kkp.go.id/arti kel/8063-tunjukkan-pertumbuhan 
Li, C., Wang, R., Su, B., Luo, Y., Terhune, J., Beck, B. and Peatman, E., 2013. Evasion of mucosal defenses during Aeromonas hydrophila infection of channel catfish (Ictalurus punctatus) skin. Developmental \& Comparative Immunology, 39(4), pp.447-455. https://doi.org/10.1016/j.dci.2012. 11.009

Lili, W., Gumilar, R., Nurhayati, A. and Rosidah, R., 2019. Effectivity of Solution Mangosteen Rind (Garciana mangostana) as Medicine for Black Tilapia Juvenile (Oreochromis niloticus Bleeker) when Infected by Aeromonas hydrophila. World Scientific News, 133, pp.56-70. http://psjd.icm.edu. $\mathrm{pl} / \mathrm{psjd} /$ element/bwmeta1.element. psjd-095d6541-9e52-4fb8-9351-97 d04cc3aacb

Majumdar, T., Datta, S., Ghosh, D., Dutta, S., Chakraborty, A., Goswami, R. and Mazumder, S., 2007. Role of virulence plasmid of Aeromonas hydrophila in the pathogenesis of ulcerative disease syndrome in Clarias batrachus. Indian Journal of Biochemistry \& Biophysics, 44(5), pp.401-406. http://nopr.niscair.res. in/handle/123456789/142

Mangunwardoyo, W., Ismayasari, R. and Riani, E., 2009. Aktivitas kitinase, lesitinase, dan hemolisin isolat bakteri dari ikan nila (Oreochromis niloticus Lin.) yang dikultur dalam keramba jaring apung Waduk Jatiluhur, Purwakarta. Jurnal Riset Akuakultur, 4(2), pp.257-265. http://dx.doi.org/10.15578/jra.4.2. 2009.257-265

Mangunwardoyo, W., Ismayasari, R. and Riani, E., 2010. Uji patogenisitas dan virulensi Aeromonas hydrophila Stanier pada ikan nila (Oreochromis niloticus Lin.) melalui postulat Koch. Jurnal Riset Akuakultur, 5(2), pp.145-255. http://dx.doi.org/10.1 5578/jra.5.2.2010.145-255

Murwani, S., Qosimah, D. and Amri, I.A., 2017. Penyakit bakterial pada hewan besar dan unggas. Universitas
Brawijaya Press, Malang, pp.134135.

Pandey, A., Naik, M. and Dubey, S.K., 2010. Hemolysin, protease, and EPS producing pathogenic Aeromonas hydrophila strain An4 shows antibacterial activity against marine bacterial fish pathogens. Journal of Marine Sciences, 563205, pp.1-9. https://doi.org/10.1155/2010/563 205

Pemberton, J.M., Kidd, S.P. and Schmidt, R., 1997. Secreted enzymes of Aeromonas. FEMS Microbiology Letters, 152(1), pp.1-10. https://doi .org/10.1111/j.1574-6968.1997.tb 10401.x

Petersen, J. and Mc Laughlin, S., 2016. Laboratory exercises in microbiology: Discovering the unseen world through hands-on investigation. CUNY Academic Works, p.66. http://academicworks. cuny.edu/qb_oers/16

Prihanto, A.A., Timur, H.D.L., Jaziri, A.A., Nurdiani, R. and Pradarameswari, K.A., 2018. Isolasi dan identifikasi bakteri endofit mangrove (Sonneratia alba) penghasil enzim gelatinase dari Pantai Sendang Biru, Malang, Jawa Timur. Indonesian Journal of Halal, 1(1), pp.31-42. https://doi.org/10.14710/halal.v1i 1.3114

Putri, E.H., Yuliani and Lisdiana, L., 2017. Identification of Isolate of Endophytic Bacteria A1 and B1 from Sweet Potato (Ipomoea batatas) Var. Papua Patippi Based on Phenotypic Character. LenteraBio: Berkala Ilmiah Biologi, 6(3), pp.62-69. https://jurnalmahasiswa.unesa.ac.i d/index.php/lenterabio/article/vie $\mathrm{w} / 22088$

Qosimah, D., Maftuch, Herawati and Khotimah, H., 2020. Pengendalian dan diagnosis penyakit ikan: Kausa bakteri dan jamur. Universitas Brawijaya Press, Malang, p.147.

Rahim, Z., Khan, S.I. and Chopra, A.K., 2004. Biological characterization of Aeromonas spp. isolated from the 
environment. Epidemiology \& Infection, 132(4), pp.627-636. https://doi.org/10.1017/S0950268 804002298

Sudheesh, P.S., Al-Ghabshi, A., AlMazrooei, N. and Al-Habsi, S., 2012. Comparative pathogenomics of bacteria causing infectious diseases in fish. International Journal of Evolutionariy Biology, Evolutionary Mechanisms of Microbial Genomes 2012, pp.1-16. https://doi.org/10.1 $155 / 2012 / 457264$

Sukmadewi, D.K.T., Anas, I., Widyastuti, R. and Cintaresmini, A., 2017. Test of Phytopathogenicity, Hemolysis and Microbial Ability in Solubilizing Phosphate and Potassium. Jurnal Ilmu Tanah dan Lingkungan, 19(2), pp.68-73. http://dx.doi.org/10.292 44/jitl.19.2.68-73

Sunita, S.C., Chaturvedi, V.K., Gupta, P.K., Sumithra T.G. and Laxmi, U., 2015. Demonstration of deoxyribonuclease activity for Bacillus anthracis and its comparison with other DNAse producing bacteria. Journal of Veterinary Public Health, 13(1), pp.1-4. https://doi.org/10.2 016/JVPH.V13I1.212

Yadav, S., Verma, D.K., Pradhan, P.K., Dobriyal, A.K. and Sood, N., 2014. Phenotypic and genotypic identification of Aeromonas species from aquatic environment. International Journal of Aquatic Science, 5(1), pp.3-20. http://www. journal-aquaticscience.com/article 73488.html 